\title{
PERANCANGAN SISTEM INFORMASI PENGINAPAN BERBASIS DEKSTOP DI PENGINAPAN A2HAY SORONG PAPUA BARAT
}

\author{
Mifta Sigit Rahmawati ${ }^{1}$, Abdilah Rahmi Purnamasari ${ }^{2}$ \\ ${ }^{1,2}$ Fakultas Teknik Program Studi Teknik Informatika Universitas Muhammadiyah Sorong
}

\begin{abstract}
A2Hay Lodging is a Home Stay located in Sorong City, West Papua, which was established in 2014 precisely in April, currently the A2Hay Inn has a total of 9 rooms. The A2Hay Lodge business process starts when making a reservation, reservations can only be made by ordering directly at the place. This research was conducted using the Waterfall method with the stages of needs analysis, system design, program code making, program testing, operation and maintenance. The results of this study are Desktop-Based Lodging Information Systems in Lodging A2hay Sorong West Papua built using Visual Basic Programming language, Microsoft Visual Studio 2010 As Program Editor, Crystall Report 13.0 As Print Report, and Microsoft Access 2010 as a database. Designing a Desktop-Based Lodging Information System at A2hay Sorong West Papua Accommodation can manage guest transaction data, data search, employee payroll and report generation.

Keywords: Information System Designing Information Systems Lodging-Based Lodging in Lodging A2hay Sorong West Papua. Waterfall, Microsoft Visual Studio, Visual Basic, Microsof Accses
\end{abstract}

\begin{abstract}
Abstrak
Penginapan A2Hay merupakan Home Stay yang terletak di Kota Sorong Papua Barat, yang berdiri sejak tahun 2014 tepatnya pada bulan april, saat ini penginapan A2Hay memiliki total 9 kamar. Proses bisnis Penginapan A2Hay dimulai saat melakukan reservasi, reservasi hanya dapat dilakukan dengan cara memesan langsung ditempat. Penelitian ini dilakukan menggunakan metode Waterfall dengan tahapan analisis kebutuhan, desain sistem, pembuatan kode program, pengujian program, operasi dan perawatan. Hasil dari penelitian ini yaitu Sistem Informasi Penginapan Berbasis Dekstop Di Penginapan A2hay Sorong Papua Barat dibangun menggunakan bahasa Pemrograman Visual Basic, Microsoft Visual Studio 2010 Sebagai Program Editor, Crystall Report 13.0 Sebagai Cetak Laporan, Dan Microsoft Access 2010 sebagai database. Perancangan Sistem Informasi Penginapan Berbasis Dekstop Di Penginapan A2hay Sorong Papua Barat dapat melakukan pengelolahan data transaksi tamu, pencarian data, penggajian karyawan dan pembuatan laporan.

Kata Kunci : Sistem Informasi Perancangan Sistem Informasi Penginapan Berbasis Dekstop Di Penginapan A2hay Sorong Papua Barat. Waterfall, Microsoft Visual Studio, Visual Basic, Microsof Accses

\section{Pendahuluan}

1.1 Latar Belakang

Teknologi informasi merupakan salah satu teknologi yang sedang berkembang pesat saat ini. Dengan kemajuan teknologi informasi, pengaksesan terhadap data atau informasi yang tersedia dapat berlangsung dengan cepat, efisien, serta akurat. Setiap perusahaan atau instansi dituntut untuk memberikan sistem pelayanan yang maksimal, yang bertujuan untuk meningkatkan kinerja suatu perusahaan yang

Penginapan A2Hay merupakan Home Stay yang terletak di Kota Sorong Papua Barat, yang berdiri sejak tahun 2014 tepatnya pada bulan april, saat ini penginapan A2Hay memiliki total 9 kamar. Proses bisnis Penginapan A2Hay dimulai saat melakukan reservasi, reservasi hanya dapat dilakukan dengan cara memesan langsung ditempat. Pada reservasi ini, pemesan akan mendapatkan informasi tentang tipe kamar yang tersedia beserta harga tiap tipe dan juga fasilitas yang tersedia.
\end{abstract} bergerak dibidang Home Stay. 
Jumlah pengunjung pada penginapan A2Hay ini tidak ditangani dengan sistem informasi atau dengan kata lain, semua proses pengolahan datanya masih ditangani secara manual yaitu dengan mencatat semua datanya di buku reservasi sementara dan belum menggunakan teknologi yang terkomputerisasi, dan hal tersebut dapat berdampak lamanya waktu dalam pembuatan laporan, serta pencarian data pun membutuhkan waktu yang lama Oleh karena itu, penulis ingin membantu menyelesaikan permasalahan ini dengan jalan membuat dan merancang sistem informasi pada Penginapan A2Hay yaitu pengolahan data tamu, data keuangan, penggajian, pencarian data, dan pembuatan laporan. Dengan adanya sistem ini maka penulis akan menyelesaikan permasalahan yang ada.

Berdasarkan uraian diatas maka penulis mengambil topik penelitian skripsi dengan judul "Perancangan Sistem Informasi Penginapan Berbasis Dekstop Di Penginapan A2Hay Sorong Papua Barat"

\subsection{Rumusan Masalah}

Berdasarkan latar belakang yang dijelaskan maka rumusan masalah yang akan dibahas dalam penelitian ini adalah :

1) Bagaimana cara membuat rancangan sistem informasi dekstop pada Penginapan A2Hay Sorong

2) Bagaimana merancang sistem yang dapat menyelesaikan masalah untuk mengetahui ketersediaan jumlah kamar, pengolahan data tamu, penggajian karyawan, pencarian data, dan pembuatan laporan?

3) Bagaimana proses penginputan data pegawai, data jenis kamar, data kamar, data tamu, data jaminan kunci, data perawatan dan kerusakan kamar, data biaya operasional, data reservasi, data check in, data check out, data penggajian karyawan penginapan pembuatan laporan, dan mencetak struk transaksi

4) Bagaimanan cara mengimplementasikan sistem informasi Penginapan A2Hay Sorong

\subsection{Maksud Dan Tujuan Penelitian}

Adapun tujuan dari penelitian ini adalah sebagai berikut :
1) Memberikan kemudahan bagi resepsionis untuk melihat jumlah ketersediaan kamar, pengolahan data transaksi tamu, pencarian data, pembuatan laporan dan mecetak nota atau struk transaksi.

2) Memudahkan bagi manager untuk melihat semua laporan data tamu, data perawatan dan kerusakan kamar, data biaya operasional, data reservasi, data check in, data check out, data penggajian karyawan, dan data keuangan

3) Menghemat waktu dan tenaga dalam proses pengolahan data, pencarian data tamu, dan pembuatan laporan dan struk transaksi

4) Membangun, serta merancang sistem informasi pemesanan kamar di Penginapan A2Hay Sorong.

5) Menerapkan ilmu penulis yang telah didapatkan selama belajar di Univeritas Muhammadiyah Sorong

\subsection{Batasan Masalah}

Berdasarkan perumusan masalah diatas, maka batasan masalah pada tugas akhir ini adalah sebagai berikut :

1) Sistem informasi penginapan hanya mengolah data tamu, data kamar, data jaminan kunci, data biaya operasional, reservasi kamar, dan data penggajian pada karyawan

2) Sistem ini dibangun dan dirancang meliputi pendataan karyawan penginapan, pendataan jenis kamar, pendataan kamar, pendataan tamu, pendataan jaminan kunci, pendataan perawatan dan kerusakan pada kamar, pendataan biaya opersional, pendataan reservasi, pendataan check in, check out, pendataan penggajian karyawan, pembuatan laporan dan mencetak struk transaksi

3) Penelitian ini dikhususkan pada Penginapan A2Hay Sorong

4) Sistem ini hanya dapat diakses oleh resepsionis dan manager penginapan A2Hay Sorong

5) Di dalam sistem ini tidak membahas diskon dan layanan pada penginapan A2Hay Sorong

6) Tamu Memesan Kamar langsung di tempat Penginapan A2Hay

7) Pembayaran transaksi penyewaan kamar dilakukaan secara manual

8) Saat kamar full sistem tidak dapat melakukan reservasi 
9) Sistem informasi dibangun berbasis dekstop dengan menggunakan Visual Studio 2010 dan databesnya menggunakan Microsoft Access 2010

10) Sistem dibangun dengan menggunakan bahasa pemrograman Visual Basic

11) Pengembangan sistem yang digunakan adalah dengan menggunakan metode waterfall

12) Sistem Informasi Penginapan A2Hay hanya dapat di akses secara offline

13) Sistem informasi PenginapanA2Hay dibangun sesuai kebutuhan pada Penginapan A2Hay

\section{Kerangka Teori}

\subsection{Sistem Informasi}

Sistem informasi adalah sistem yang dapat mengumpulkan, memproses, menyimpan, menganalisis dan menyebarkan informasi untuk tujuan tertentu. Sistem informasi terdiri atas input berupa data dan intruksi, dan output berupa laporan dan kalkulasi. (Sutarman, 2009)

\subsection{Microsoft Visual Studio}

Visual Studio 2010 pada dasarnya adalah sebuah bahasa pemrograman komputer. Dimana pengertian dari bahasa pemrograman itu adalah perintah-perintah atau intruksi yang dimengerti oleh komputer untuk melakukan tugas-tugas tertentu. Visual Studio 2010 (yang sering disebut juga dengan VB. Net 2010) selain disebut dengan Bahasa pemrograman, juga sering disebut sebagai sarana (tool) untuk menghasilkan program-program aplikasi berbasiskan Windows. (Sadeli, 2010)

\subsection{Microsoft Visual Basic}

Microsoft Visual Basic sering disingkat sebagai VB merupakan sebuah bahasa pemrograman yang menawarkan Integrated Development Environtment (IDE) visual untuk membuat program perangkat lunak berbasis sistem operasi Microsft Windows menggunakan model pemrograman (COM) Visual Basic merupakan turunan bahasa pemrograman basic dan menawarkan perkembangan perangkat lunak computer berbasis grafik dan cepat. (Stafeno, 2014)

\subsection{Microsoft Access}

Microsoft Access adalah program aplikasi untuk mengolah basis data model rasional, karena terdiri dari lajur kolom dan lajur baris. Selain itu Microsoft Access merupakan program aplikasi yang sangat mudah dan familiar dalam pembuatan dan perancangan sistem manajemen basis data. (Purba, 2017)

\subsection{Power Designer}

Power Designer Meruapakan tool pemodelan yang dikeluarkan oleh Sybase untuk membangun sebuah sistem iformasi yang cepat, terstruktur dan efektif. Power Designer menggunakan format file pdm. (Kusumawardani \& Wardati, 2014)

\subsection{Crystal Report}

Crystal Report merupakan program yang terpisah dengan program Microsoft Visual Basic, tetapi keduanya dapat dihubungkan (Linkage). Membuat laporan dengan Crystal Report hasilnya lebih baik dan lebih mudah, karena pada Crystal Report banyak tersedia objek-objek maupun komponen yang mudah digunakan. (Andi, 2010)

\subsection{Metode Waterfall}

Metode air terjun atau yang sering disebut metode Waterfall sering dinamakan siklus hidup klasik (Classic Life Cycle), dimana hal ini menggambakan pendekatan yang sistematis dan juga berurutan pada pengembangan perangat lunak. Tahapan metode Waterfall dapat dilihat pada gambar dibawah ini. (Galandi, 2017)

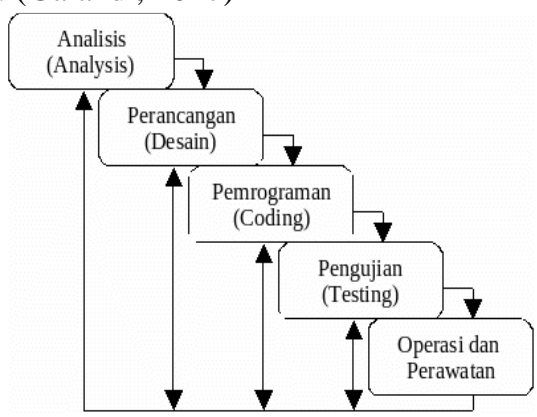

Gambar 1. Tahapan Metode Waterfall

\section{Metode Penelitian}

\subsection{Bagan Alir Penelitian}

Skema bagan alir dalam tahapan penelitian tentang sistem informasi Penginapan A2Hay Sorong, dapat dilihat pada gambar skema dibawah ini : 


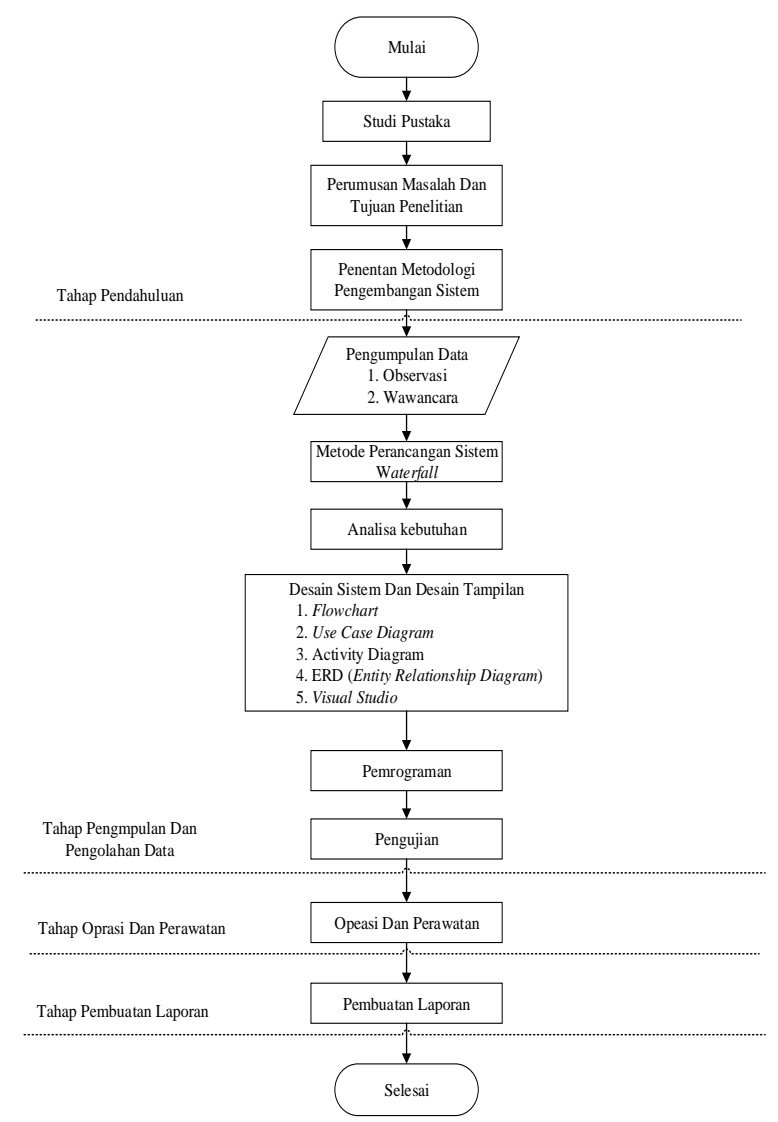

Gambar 3. Bagan Alir Penelitian

\section{Hasil Dan Pembahasan}

\subsection{Analisa Kebutuhan}

a. Analisa Kebutuhan Fungsional

Berdasarkan hasil penilitian yang dilakukan oleh peniliti yaitu dengan melakukan wawancara, observasi, dokumentasi dan studi pustaka, maka dapat disimpulkan kebutuhan fungsional sebagai berikut :

1. Sistem memiliki dua jenis user yaitu Manger dan Resepsionis. Manger memiliki hak akses full terhadap sistem pada Penginapan A2Hay, sedangkan Resepsionis sebagai pengguna yang bertugas menginputkan dan mengolah data-data tamu Penginapan A2Hay

2. Sistem hanya dapat diakses jika user melakukan login kedalam sistem

3. Manger memiliki tugas dalam sistem, antara lain

a. Dapat Melihat semua data yang ada pada sistem diantaranya data pegawai, data tamu, data jaminan kunci, data perawatan dan kerusakan pada fasilitas kamar, data biaya operasional, data reservasi, data chek in, data check out, data penggajianDapat Melihat semua laporan yang ada pada sistem diantaranya laporan data tamu, laporan data perawatan dan kerusakan pada fasilitas kamar, laporan biaya operasional, laporan data reservasi, laporan data chekin, laporan data checkout, dan laporan data penggajian

b. Merubah password untuk login

4. Resepsionis Memiliki tugas dalam sistem antara lain :

a. Menginputkan dan mengolah semua data di antaranya data jenis kamar, data kamar, data tamu, data jaminan kunci, data perawatan dan kerusakan kamar, data biaya operasional, data reservasi, data checkin dan data checkout

b. Melihat dan mencetak laporan diantaranya laporan data tamu, laporan Biaya Operasional dan cetak struk transaski

\subsection{Analisa Kebutuhan Softwere}

Kebutuhan perangkat lunak merupakan program-program yang dibutuhkan dalam pengembangan sisitem informasi Penginapan A2Hay Sorong, agar berjalan dengan baik

1. Sistem Operasi Windows 764 bit

2. Microsoft Office 2010

3. Microsoft Visio 2016

4. Power Desiger

5. Microsoft acces 2010

6. Visual basic

7. Visual Studio 2010

8. Crystal report

b. Analisa Kebutuhan Hardware

Kebutuhan peangkat keras dapat diartikan sebagai suatu komponen yang berbentuk secara fisik dan nyata. Perangkat keras yang dilakukan dalam penelitian yaitu Laptop Asus Intel Pentium Inside, Ram 4 Gb, dan Flashdisk.

\subsection{Flowchart system}

Flowchart ini menjelakan bagaimana urutanurutan dari prosedur yang ada dalam sistem dan menunjukan apa yang dikerjakan oleh user, dapat dilihat pada gambar 4 dibawah ini 


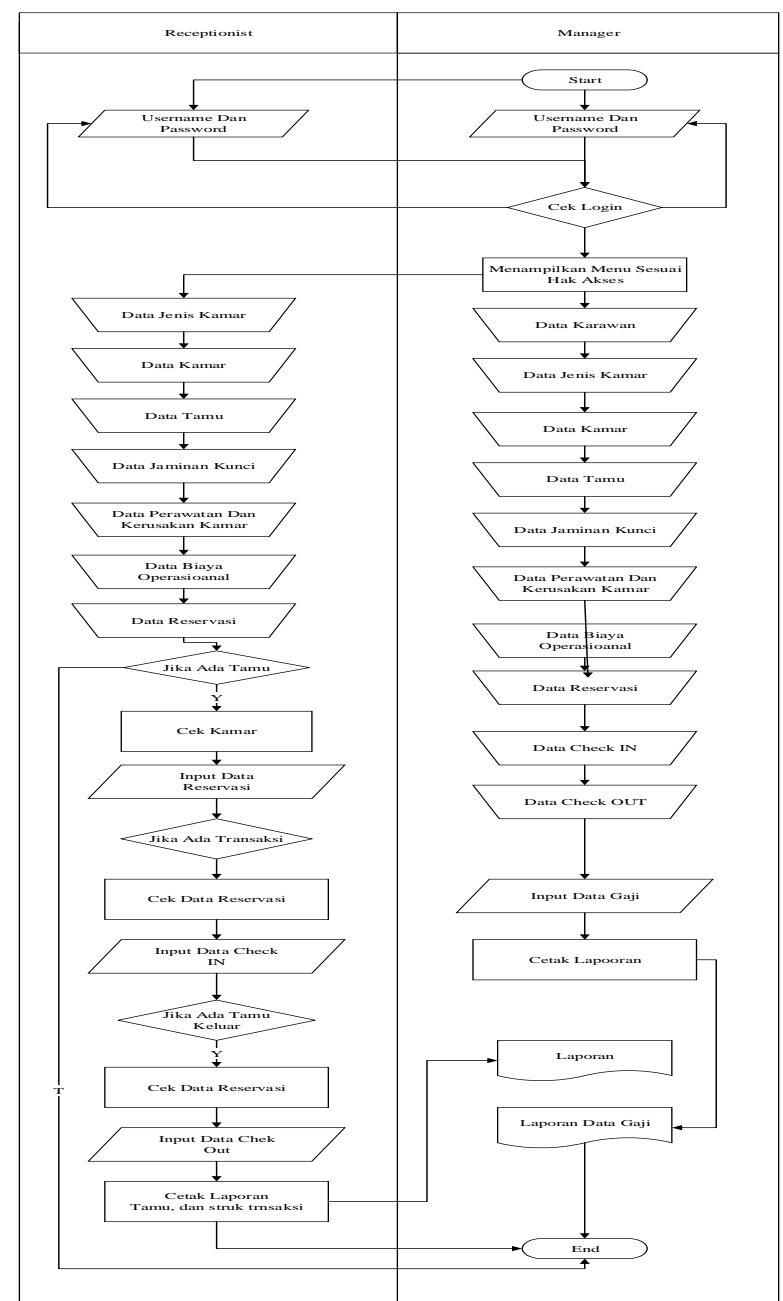

Gambar 4. Flowchart Sistem

\subsection{UML}

1. Use Case Diagram

a. Definisi Aktor

Berikut adalah defiisi aktor pada sistem informasi Penginpan A2hay berbasis dekstop dapat dilihat pada tabel berikut :

Tabel 4.1 Aktor Dalam Sistem Informasi Penginapan A2Hay

\begin{tabular}{|c|c|c|}
\hline $\begin{array}{c}\mathrm{N} \\
\mathrm{o}\end{array}$ & Aktor & \multicolumn{1}{|c|}{ Deskripsi } \\
\hline 1. & Manager & $\begin{array}{l}\text { Aktor yang memiliki hak akses full } \\
\text { pada sistem dan dapat mencetak } \\
\text { seluruh data yang ada pada sistem. } \\
\text { Manager juga bertanggung jawab } \\
\text { untuk menginput data pegawai, data } \\
\text { user, mengganti password pada user } \\
\text { dan menginput data gaji karyawan } \\
\text { yang ada pada Penginapan A2Hay }\end{array}$ \\
\hline
\end{tabular}

\begin{tabular}{|c|c|l|}
\hline 2. & $\begin{array}{c}\text { Receptioni } \\
\text { st }\end{array}$ & $\begin{array}{l}\text { Aktor yang bertanggung jawab } \\
\text { menginput data jenis kamar, data } \\
\text { kamar, mengelolah data transaksi } \\
\text { tamu, data tamu masuk, tamu keluar } \\
\text { data jaminan kunci, data perawatan } \\
\text { dan kerusakan kamar, data biaya } \\
\text { operasional dan mencetak laporan } \\
\text { data tamu, dan mencetak struk } \\
\text { transaksi }\end{array}$ \\
\hline
\end{tabular}

b. Gambaran use case diagram yang diuslkan dalam pembuatan sistem informasi Penginapan A2Hay Sorong Papua Barat

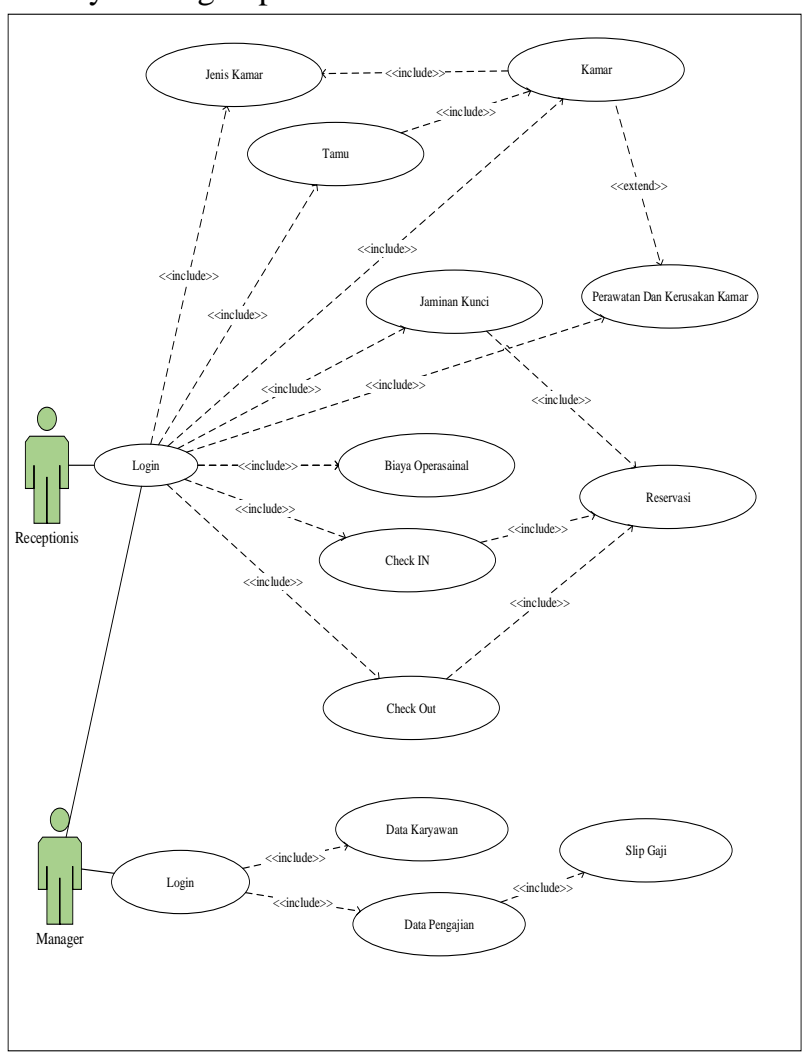

Gambar 5. Use Case Diagram

\section{Activity Diagram}

Berikut adalah activity diagram atau diagram aktivitas yang diusulkan dari pembuatan perancangan sistem informasi penginapan berbasis dekstop di Penginapan A2Hay Sorong Papua Barat

a. Activty Diagram Login

Menggambarkan aliran aktifitas user dapat login ke menu utama program. Activty Diagram Login dapatdilihat pada gambar 6 


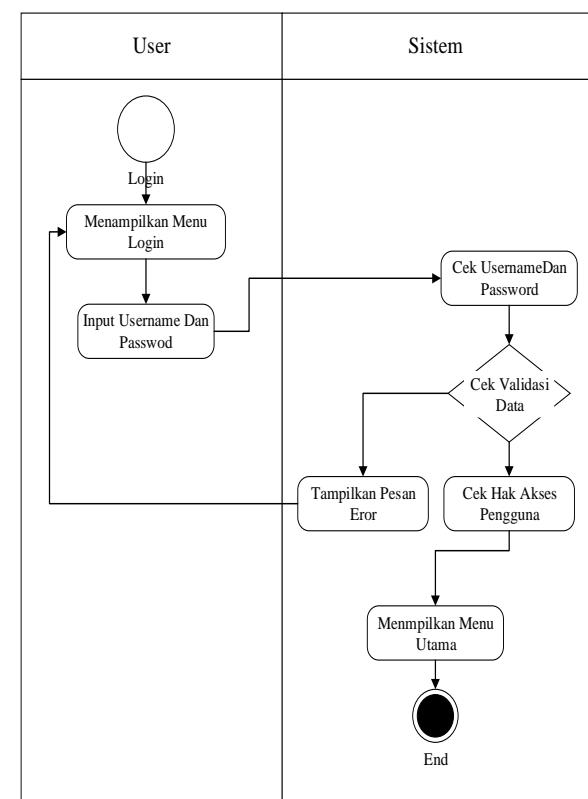

Gambar 6. Activity Diagram Login

b. Activty Digram Input Data

Menggambarkan aliran aktivitas user yang dapat menambah data sesuai dengan menu data yang dipilih. Activty Digram input data dapat dilihat pada gambar 7

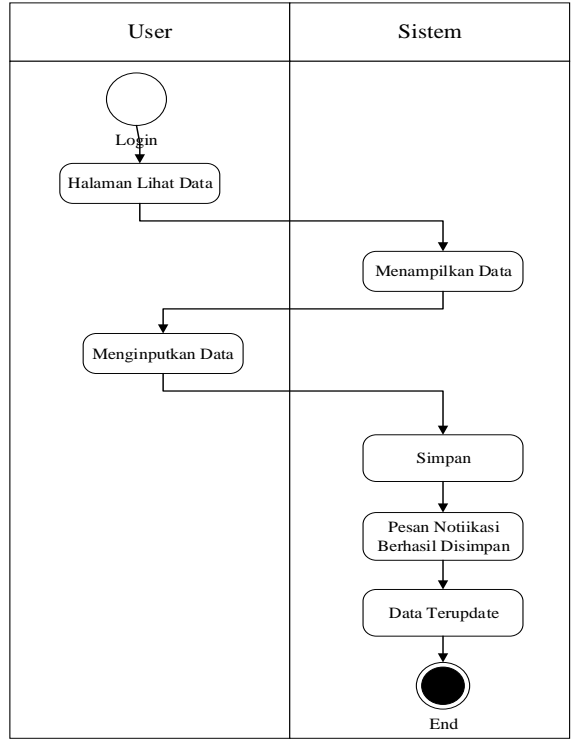

Gambar 7. Activity Diagram Input Data

c. Activity Diagram Edit Data

Menggambarkan aliran aktifitas user dapat mengubah data sesuai dengan menu data yang dipilih Actifity Diagram edit data dapat dilihat pada gambar 8

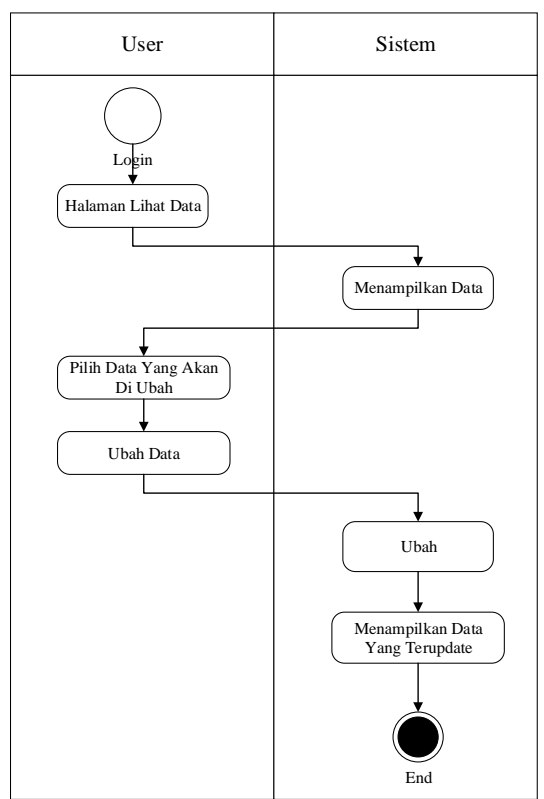

Gambar 8. Activity Diagram Edit Data

d. Activity Diagram Hapus Data

Menggambarkan aliran aktifitas user dapat melihat user data sesuai dengan menu data yang dipilih. Activity Diagram mengahpus data dapat dilihat pada gambar 9

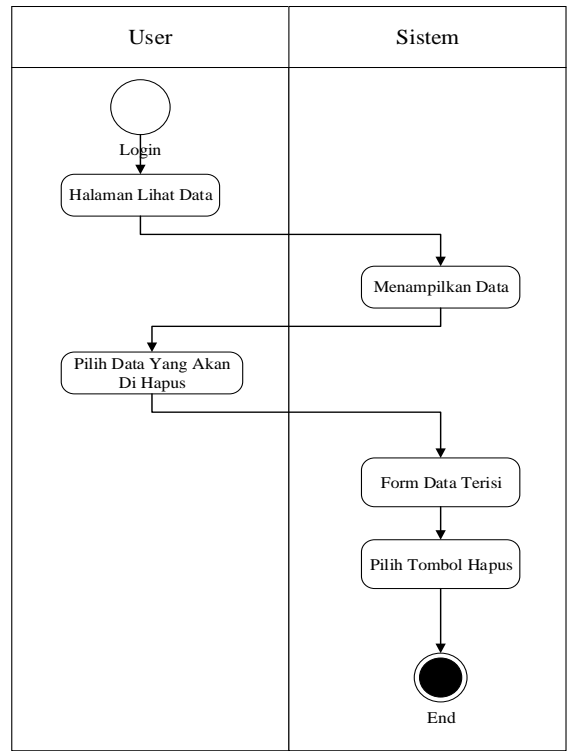

Gambar 9. Activity Diagram Hapus Data

e. Activity Diagram Pencarian Data

Menggambarkan aliran aktifitas user saat melakukan pencarian data tertentu, sesuai dengan menu data yang dipilih. Activity Diagram pencarian data dapat dilihat pada gambar 10 


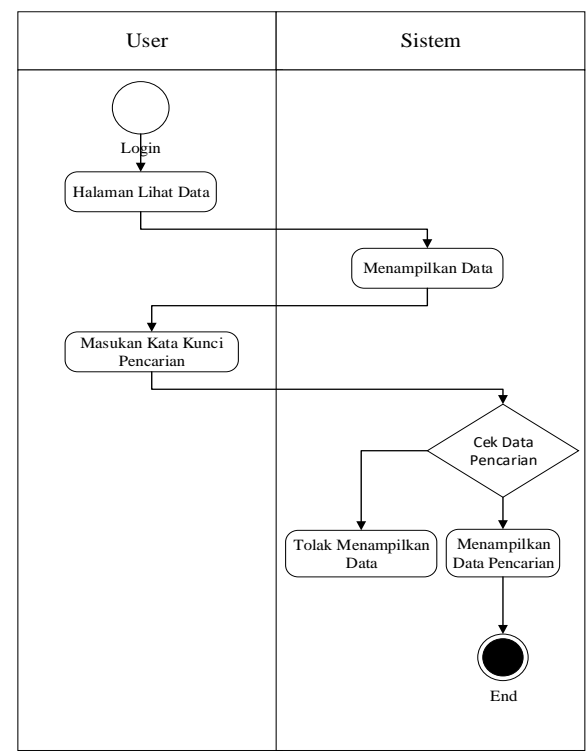

Gambar 10. Acivity Daiagram Cari Data

\section{f. Aktivity diagram cetak data}

Menggambarkan aliran aktitas user saat melakukan cetak data, sesai dengan menu data yang dipilih. Activity Diagram cetak data dapat dilihat padaa gambar 11

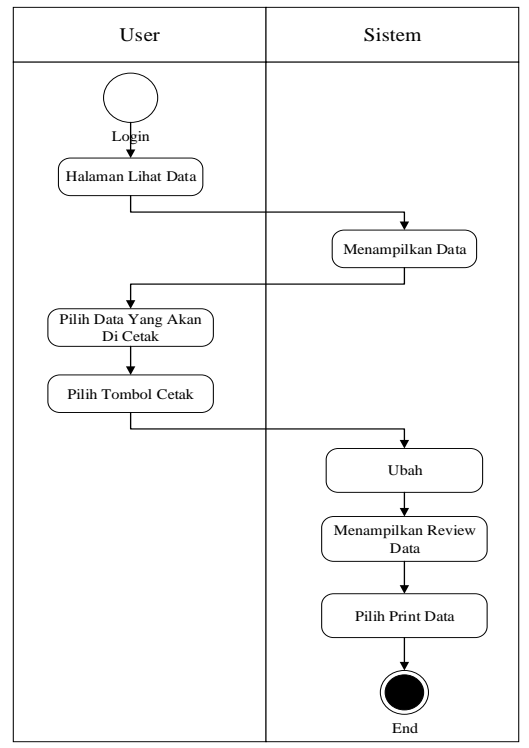

Gambar 11. Acivity Diagram Cetak Data

Entity Relationship Diagram (ERD)

Untuk pengembangan aplikasi pemodelan basis data yang digunakan adalah Entity Relationship Diagram (ERD). ERD merupakan diagram yang digunakan untuk merancang basis data dan memperlihatkan relasi antar entitas atau objek dengan atributnya

Tujuan ERD dalam pengembangan aplikasi adalah dapat membeikan gambaran umum tentang sistem yang dikembangkan sehingga memudahkan dalam merancang basis data. Gambaran ERD dalam Conceptual Data Model (CDM) dan Physical Data Model (PDM) yang digunakan pada aplikasi dapat dilihat pada gambar berikut. Gambar diagram Entity Relationship Diagram (ERD) dapat dilihat pada gambar 12

1. Conceptual Data Model
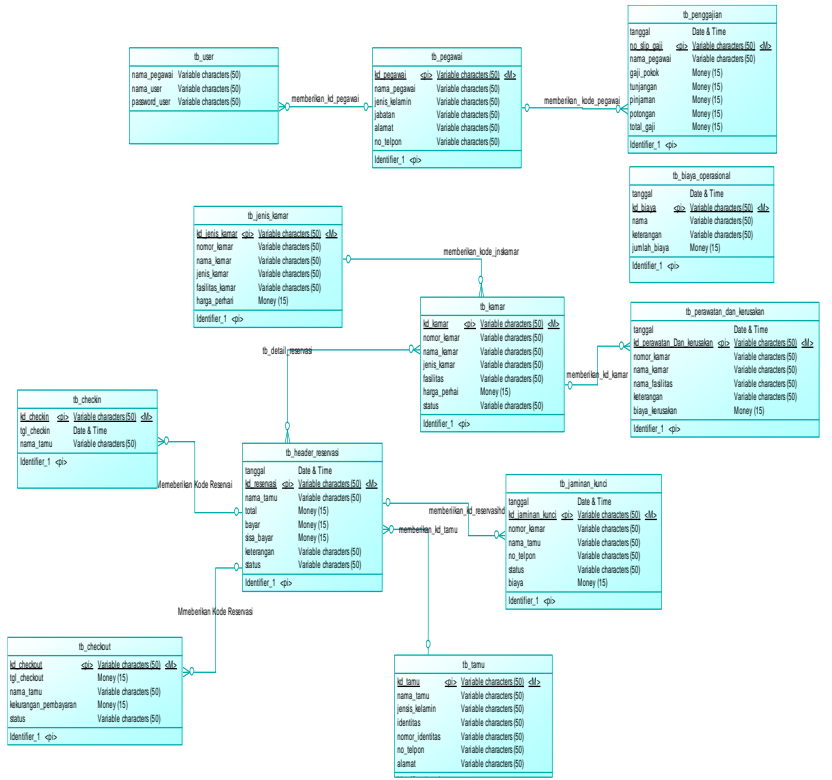

Gambar 12. Conceptual Data Model

2. Physical Data Model

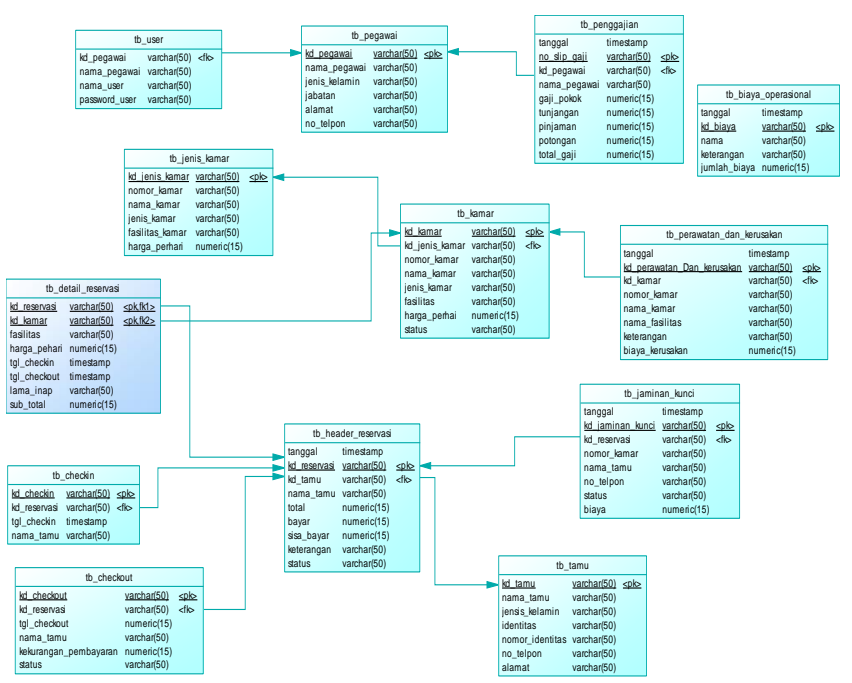

Gambar13. Physical Data Model 


\subsection{Implementasi}

Implemetasi interface merupakan tampilan menumenu yang ada pada Sistem Informasi Pengnapan A2Hay

1. Halaman Halaman Login

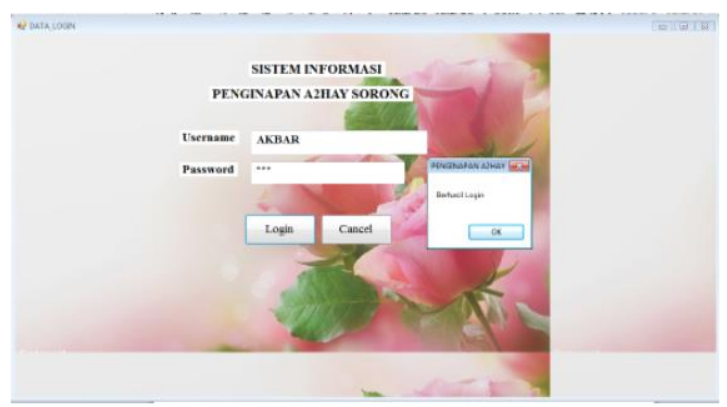

Gambar 14. Halaman Halaman Login

2. Halaman Menu Utama

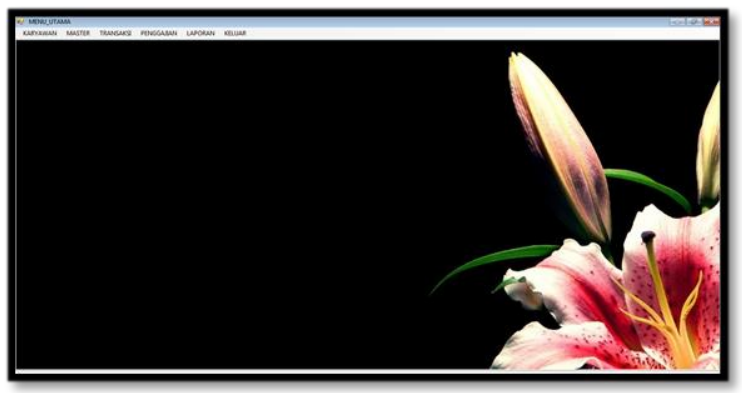

Gambar 15. Halaman Menu Utama

3. Halaman Data Kamar

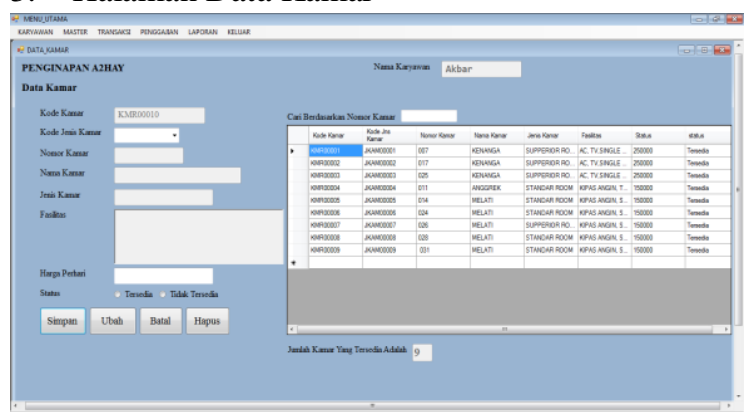

Gambar 16. Halaman Data Kamar

4. Halaman Data Tamu

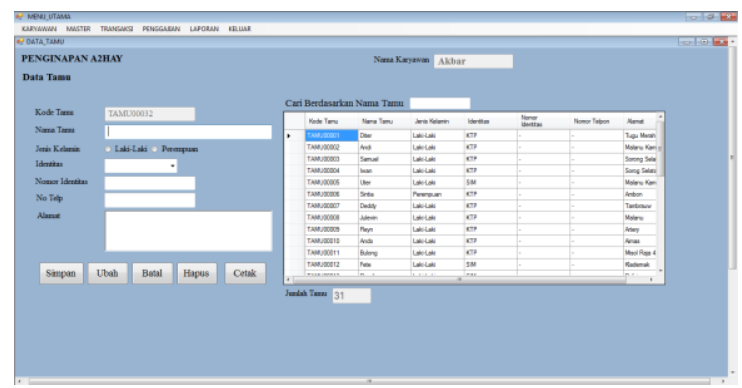

Gambar 17. Halaman Data Tamu
5. Halaman Data Jaminan Kunci

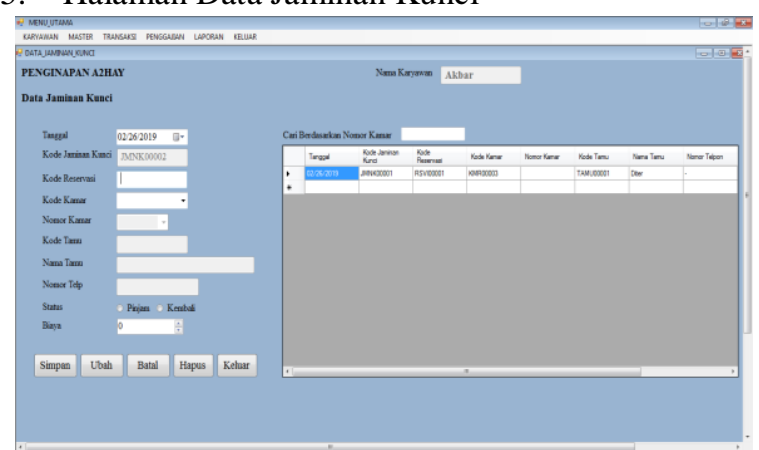

Gambar 18. Halaman Data Jaminan Kunci

6. Hal Data Perawatan Dan Kerusakan Kamar

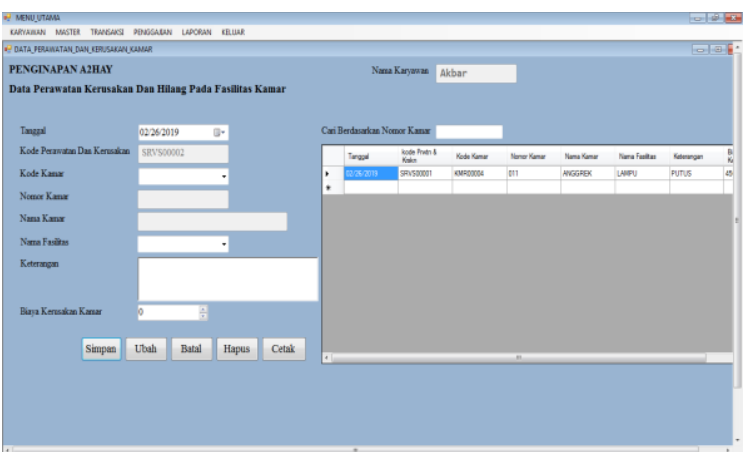

Gambar 19. Hal Data Perawatan Dan Kerusakan

7. Tampilan Halaman Data Biaya Operasional

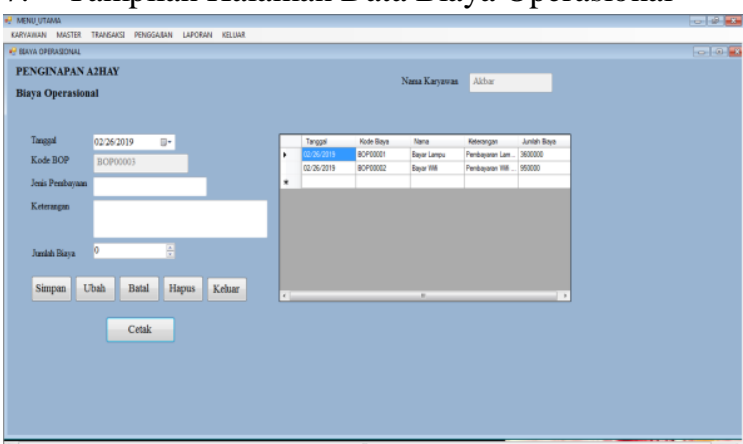

Gambar 20. Form Data Biaya Operasional

8. Tampilan Halaman Data Reservasi

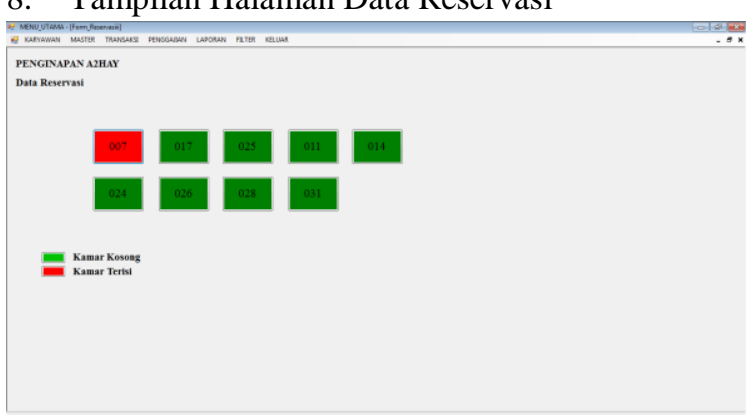

Gambar 21. Form Data Reservasi 


\section{Halaman Data Penggajian}

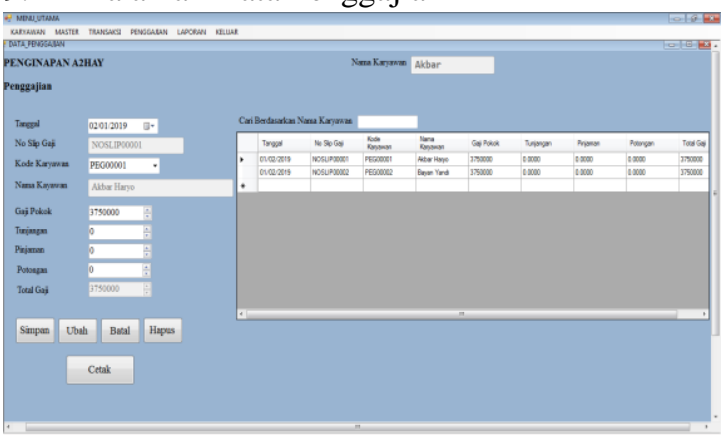

Gambar 22. Form Data Penggajian

10. Laporan Slip Gaji Karyawan

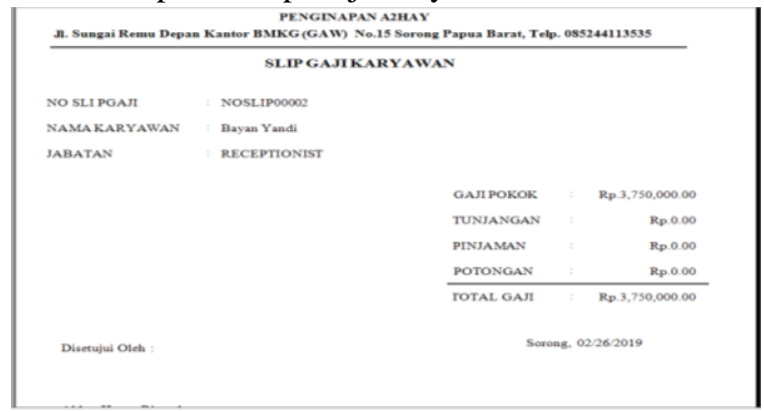

Gambar 23. Laporan Slip Gaji Karyawan

11. Laporan Struk Transaksi

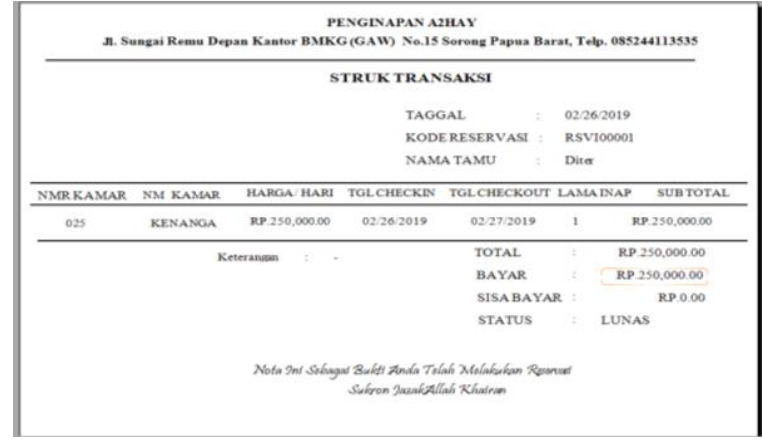

Gambar 24. Laporan Struk Transaksi

12. Laporan Resevasi

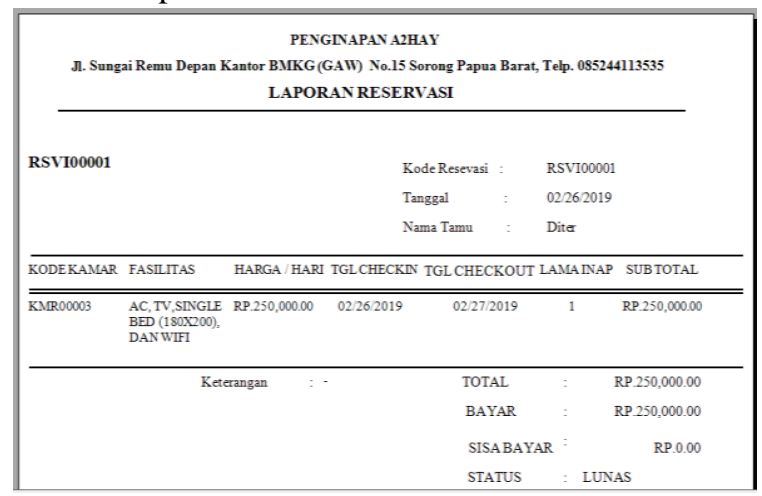

Gambar 25. Laporan Resevasi

\subsection{Pengujian}

pengujian dilakukan untuk mengetaui apakah terdapat trouble atau error pada sistem. pengujian dilakukan dengan menggunakan metode black box yaitu pengujian fungsi-fungsi yang ada pada sistem.

\section{Penutup}

Berdasarkan hasil pembuatan sistem yang telah dilakukan, maka penulis dalam hal pembuatan sistem mencoba membuat suatu kesimpulan dan mengajukan beberapa saran yang berhubngan dengan pembahasan yang telah di kemukakan di bab-bab sebelumnya

\subsection{Kesimpulan}

Sistem mampu dan sisitem dapat mengerjakan :

1. Memberikan kemudahan bagi Receptionist untuk melihat jumlah ketersediaan kamar, pengolahan data transaksi tamu, pencarian data, pembuatan laporan dan mecetak nota atau struk transaksi.

2. Memudahkan bagi manager untuk melihat semua laporan data tamu, data perawatan dan kerusakan kamar, data biaya operasional, data reservasi, data check in, data check out, data penggajian karyawan, dan data keuangan

3. Menghemat waktu dan tenaga dalam proses pengolahan data, pencarian data tamu, dan pembuatan laporan dan struk transaksi

4. Membangun, serta merancang sistem informasi pemesanan kamar di Penginapan A2Hay Sorong.

5. Menerapkan ilmu penulis yang telah didapatkan selama belajar di Univeritas Muhammadiyah Sorong

\subsection{Saran}

Penulis sangat menyadari bahwa dalam pembuatan aplikasi dan laporan ini masih banyak terdapat kekurangan sehingga kritik da saran dari pembaca sangat diharapkan.

Untuk kedetailan informasi atau penglahan sistem informasi penginapan maka dibutuhkan laporan penunjang lainya yaitu laporan pendapatan, laporan pengeluaran, dan laporan laba rugi. Maka diharapkan untuk saran pengembangan dapat dibuat laporan pendapatan, lapoan pengeluaran dan laporan laba rugi dalam sistem tersebut dan dapat membuat tampilan sistem yang lebih menarik. 


\section{DAFTAR PUSTAKA}

Aplikasi Receptionist Abna Hotel. (2013). Aplikasi Receptionist Abna Hotel Dengan Menggunakan Visual Basic dan Database Acces.

A.S, Rossa, \& M. Shalahuddin. (2013). Rekayasa Perangkat Lunak Terstruktur Dan Berorientasi Objek. Bandung: Penerbit Informatika.

Andi. (2010). Microsoft Visual Basic 6.0 dan Crystal Report. Yogyakarta: C.V Andi Offset.

Galandi, F. (2017). Metode Waterfall : Definisi, Tahapan, Kelebihan dan Kekurangan.

Jogiyanto. (2010). Analisis dan Desain Sistem Informasi. Yogyakarta.: Edisi IV, Andi Offset.

Kusumawardani, L. (2013). Pembangunan Sistem Informasi Pada Hotel Graha Prima Pacitan. Surakarta: Fakultas Teknologi Informatika.

Kusumawardani, L., \& Wardati, U. I. (2014). Analisis Dan Perancangan Sistem Informasi Hotel Graha Prima Pacitan Sentra Penelitian Engineering dan Edukasi, 6(3), 26-31.

Ladjamudin, B. A.-B. (2013). Analisis dan Desain Sistem Informasi. Yogyakarta: Graha.

Markito, L., \& Yulianto, L. (2013). Rancang Bangun Sistem Informasi Front Office Hotel Minang Permai Pacitan. Indonesian Journal on Networking and Security, 1-6.

Mustakim, \& Krisnawati. (2013). Analisis Dan Perancangan Sisitem Informasi Aakutansi Laporan Keuangan Pada Pusat Perusahaan Distributor Air Mineral Mq Jernih Yogyakarta. Ilmiah DASI, 14(4), 26-30.

Mustaqbal, M. S. (2015). Pengujian Aplikasi Menggunakan Black Box Testing Boundary Value Analysis. Jurnal Ilmiah Teknologi Informasi Terapan Universitas Widyatama, 32-33.

Pahlevy. (2010). Rancang Bangun Sistem pendukung Keputusan Menentukan penerima Beasiswa dengan Menggunakan metode Simpele Additive Weighting (SAW). Surabaya: Universitas Pembangunan Nasional Veteran Surabaya.

Prabowo, A., \& Retnoningsih, E. (2017). Sistem Informasi Reservasi Kamar Hotel Pada Hotel Posters MICE. Jurnal Mahasiswa Bina Insani, 1(2), 147-160.

Prasetyo, Y. D. (2015). Sistem Informasi Manajemen Hotel Arrahman Tembilahan Berbasis Web (Online) Pada Hotel Arrahman Tembilahan. Sistemasi, 4(3), 25-34.
Purba, M. (2017). Perancangan Aplikasi Penjualan Pada PT. Mustrakom. Jurnal Informatika, 6(1), 57-65.

Sadeli, M. (2010). Belajar Interaktif Microsoft Visual Studio 2010 Untuk Pemula . Yogyakarta: Informatika.

Soekarta, R. (2015). Rancang Bangun Sistem Informasi Akademik Berbasis Web (Studi Kasus Universitas Muhammadiyah Sorong). Insect (Informatics And Security): Jurnal Teknik Informatika, 1(1), 1-8.

Soetam, R. (2011). Kosep Dasar Rekayasa Perangkat Lunak. Jakarta: PT. Prestasi Pustakarya.

Wiliani, Ninuk, dan Syadid Zambi. Rancang Bangun Aplikasi Kasir Tiket Nonton Bola Bareng pada X Kasir Disuatu Lokasi X Dengan Visual Basic 2010 Dan Mysql. Jakarta: Jurnal Rekayasa Informasi, 2017.

Soetam, Rizky. Kosep Dasar Rekayasa Perangkat Lunak. Jakarta: PT. Prestasi Pustakarya, 2011.

Yulansari, K. "Sistem Informasi Pengolahan Data Luaran Badan Pembantu Penyelengaraan Pendidikan Sekolah Menengah Kejuruan Negri 2 Donorojo." In Seruni-Seminar Riset Unggulan Nasional Informatika dan Komputer 2, no. 1 (2013).

Florentika. Perancangan Sistem Informasi Pejualan Produk Kecantikan Pada Ch Makeup Studio Berbasis Web. Batam: Program Studi Sistem Informasi Sekolah Tinggi Manajemen Informatika Dan Komputer(STMIK) Gici Batam, 2017.

Purba, Mariana. "Perancangan Aplikasi Penjualan Pada PT. Mustrakom." Jurnal Informatika 6, no. 1 (2017): 57-65.

Susanto, Azhar. Sistem Informasi Akuntansi. Bandung: Lingga Jaya, 2013.

Mulyadi. Sisitem Akuntansi, Edisi ke-3. Jakarta: Salemba Empat, 2010.

Sutarman. Pengantar Teknologi Informasi. Jakarta: Bumi Aksara, 2009.

Sutabri, Tata. Analisis Sistem Informasi. Yogyakarta: Andi Offset, 2012.

Taufiq, Rohmat. Fakta Menakjubkan Tentang Internet. www.liputan6.com, 2016. 
Mahdiana, Deni. Analisa dan Rancangan Sistem Informasi Pengadaan Barang engan Metodologi Berorientasi Obyek Studi Kasus PT. Liga Indonesia. Jakart: Fakultas Teknologi Informasi Universitas Budi Luhur, 2011.

Zohrahayati. Perancangan Sistem Informasi Penjualan Pada Butik Luwes Fashion Kecamatan Tulakan. Surakart: Surakarta, 2013.

Wahono, Roso. Sistem Informasi Penginapan Wisma Assalam. Surakarta: Fakultas Matematika Dan Ilmu Pengetahuan Alam Universitas Sebelas Maret Surakarta, 2007.

Sadeli, Muhammad. Belajar Interaktif Microsoft Visual Studio 2010 Untuk Pemula . Yogyakarta: Informatika, 2010.

Stafeno. Cara Mudah Membangun Sistem Informasi Menggunakan VB.Net dan Komponen Dexperince. Yogyakarta: Andi, 2014.

Mustakim, dan Krisnawati. "Analisis Dan Perancangan Sisitem Informasi Aakutansi Laporan Keuangan Pada Pusat Perusahaan Distributor Air Mineral Mq Jernih Yogyakarta.” Ilmiah DASI 14, no. 4 (2013): 26-30.

Laurenzo, Maria. Perancangan Sistem Informasi Penjualan Obat Di Apotik Rezka Farma Berbasis Visual Basic 6.0. Batam: Program Studi Manajemen Informatika Sekolah Tinggi Manajemen Informatika Dan Komputer (STMIK) Gici Batam, 2017.

Zuliadin, Ilham. Pengertian Microsoft Office. Tugas Mahasiswa Teknik, 2017.

Kusumawardani, Lia, dan Uly Indah Wardati. Analisis Dan Perancangan Sistem Informasi Hotel Graha Prima Pacitan Sentra Penelitian Engineering dan Edukasi 6, no. 3 (2014): 26-31.

Andi. Microsoft Visual Basic 6.0 dan Crystal Report. Yogyakarta: C.V Andi Offset, 2010.

Nurullah. "Perancangan Dan Pembuatan Sistem Informasi VB. Net." Banda Aceh: Program Studi Komputer Akutansi Sekolah Tinggi Manajemen Informatika Dan Komputer U' Bidayah Indonesia Banda Ace , 2012.
Sudharyana, Putu, dan Dkk. "Rancang Bangun Sistem Penilaian Indek Kepuasan Pegawai Terhadap Lingkungan Kerja Melalui Dasbhord Terintegrasi Dengan Menggunakan Metode Prototipe Studi Kasus PT. PLN (Persero) Area Bali Selatan." Teknik Pomits (Fakultas Teknik Informasi, Jurusan Sistem Informasi, Kampus ITS Sukolilo, Surabaya.) 1, no. 1 (2012): 1-6.

Mustaqbal, M Sidi. "Pengujian Aplikasi Menggunakan Black Box Testing Boundary Value Analysis." Jurnal Ilmiah Teknologi Informasi Terapan Universitas Widyatama, 2015: 32-33.

Galandi, Fitho. Metode Waterfall : Definisi, Tahapan, Kelebihan dan Kekurangan. 2017.

Ewolf, Community. Buku Wajib Programmer: Indeks Lengkap Syntax Kumpulan Perintah-perintah Dasar Pemrograman yang Sering Digunakan Visual Basic, Delphi, C++, HTML, JavaScript, PHP, dan SQL. Yogyakarta: MediaKom, 2011.

Indrajani. Perancangan basic data all in 1. Jakarta: Alex, 2011.

A.S, Rossa, dan M. Shalahuddin. Rekayasa Perangkat Lunak Terstruktur Dan Berorientasi Objek. Bandung: Penerbit Informatika, 2013.

Ladjamudin, Bin Al-Bahra. Analisis dan Desain Sistem Informasi. Yogyakarta: Graha, 2013.

Sukamanto, R A, dan M Shalahudin. Rekayasa Perangkat Lunak Terstruktur Dan Berorientasi Objek. Bandung: Informatika Bandung, 2014.

Minarni, dan Susanti. "Siitem Informasi Inventory Obat Pada Rumah Sakit Umum Daerah (RSUD) Padang.” Jurnal Momentum 16, no. 1 (2014): 103-111.

Isawandi, Eka. "Sisitem Penunjang Keputusan Untuk Menentukan Penerimaan." Jurnal TEKNOIF 3, no. 2 (2015): 70-79.

Supriyanto, dan Muhsin. Tekhnologi Informasi Perpustakaan. Jakarta: Erlangga, 2008.

Tantara, dan Rudi. Manajeman Proyek Sistem Informasi. Jakarta: Erlangga, 2012.

Nurjaman, Rizky. "Aplikasi Sistem Informasi Skripsi Dan Tugas Akhir Berbasis Android Studi Kasus 
Program Studi Sistem Informasi Unikom.” Jurnal Fakultas Teknik Dan Ilmu Komputer Universitas Komputer Indonesia, 2014.

Yuliastrie, Junaidi Tiara Nenden Dewi, dan Khanna. Sistem Pakar Monitoring Inventory Control Untuk Menghitung Harga Jual Efektif Dalam Meningkatkan Keuntungan. Yogyakarta: Universitas Ahmad Dahlan, 2013.

Jogiyanto. Analisis dan Desain Sistem Informasi. Yogyakarta.: Edisi IV, Andi Offset, 2010.

Pahlevy. Rancang Bangun Sistem pendukung Keputusan Menentukan penerima Beasiswa dengan Menggunakan metode Simpele Additive Weighting (SAW). Surabaya: Universitas Pembangunan Nasional Veteran Surabaya, 2010.

Hafrizal, Okta Ade Putra. Sistem Pengolahan Data. Jurnal Sisitem Informasi Manajemen, 2013.

Markito, Luki, dan Lies Yulianto. "Rancang Bangun Sistem Informasi Front Office Hotel Minang Permai Pacitan." Indonesian Journal on Networking and Security, 2013: 1-6.

Irwan, dan Ivan Jevrison. Sistem Informasi Penjualan Obat Di Toko Obat 21 Bandung. Bandung: Jurusan Manajemen Informatika Fakultas Teknik Dan Ilmu Komputer Universitas Komputer Indonesia, 2009.

Kaharu, Sarintan, dan Oki Sakina. "Perancangan Sistem Informasi Pengolahan Data Akademik." Jurnal Elektronik Sistem Informasi dan Komputer 2, no. 1 (2016): 30-41.

Kusumawardani, Lia. Pembangunan Sistem Informasi Pada Hotel Graha Prima Pacitan. Surakarta: Fakultas Teknologi Informatika, 2013.

Prasetyo, Yuli Dwi. "Sistem Informasi Manajemen Hotel Arrahman Tembilahan Berbasis Web (Online) Pada Hotel Arrahman Tembilahan." Sistemasi 4, no. 3 (2015): 25-34.

Vickyantoro, Hari. Pembuatan Sistem Informasi Reservasi Kamar Menggunakan Visul Basic.NET Pada Hotel Omah'e Sun Condongcatur Yogyakarta. Yogyakarta: Sekolah Tinggi Manajemen Informatika Dan Komputer, 2014.
Wibowo, Beni. Rancang Bangun Sistem Informasi Reservasi Reservasi Sewa Kamar Hotel Berbasis Web (Studi Kasus Hotel Gren Mandarin Pekalongan). Semarang: Fakultas Teknologi Informasi, 2014.

Prabowo, Ari, dan Endang Retnoningsih. "Sistem Informasi Reservasi Kamar Hotel Pada Hotel Posters MICE." Jurnal Mahasiswa Bina Insani 1, no. 2 (2017): 147-160.

"Aplikasi Receptionist Abna Hotel." Aplikasi Receptionist Abna Hotel Dengan Menggunakan Visual Basic dan Database Acces (Pogram Studi Sistem Informasi Fakultas Teknik Universitas Widyatama Bandung), 2013.

Perkasa, Dheru Alam, Eki Saputr, dan Mona Fronit. "Sistem Ujian Online Essay dengan Penilaian Menggunakan Metode Latent Sematic Analysis (LSA)." Jurnal Rekayasa dan Manajemen Sistem Informasi Vol.1, no. No.1 (Februari 2015).

Bobby Melky Tulangouw. "Sistem Ujian Berbasis Web." jurnal teknologi dan informatika vol.1 (2011).

Antony Susanto, dan Henky Susanto. "Perancangan Ujian Online pada STMIK GI MDP.” Jurnal Informatika, 2013.

Muhamad Son Muarie. "Rancang Bangun Sistem Ujian Online pada SMP Negeri 8 Sekayu." Jurnal Teknik Informatika Politeknik Sekayu (TIPS) Vol II, no. No. 1 (Maret 2015).

Sri Hartati, dan Ricky Wijaya. "Implementasi Web Goverment sebagai Media Informasi Potensi Desa Sukaraja." Jurnal TAM (Technology Acceptance Model) Vol.7 (2016).

Rochmawati Daud, dan Valeria Mimosa Windana . "Pengembangan Sistem Informasi Akuntansi Penjualan dan Penerimaan Kas Berbasis Komputer pada Perusahaan Kecil (Studi Kasus Pada PT.Trust Technology)." Jurnal Manajemen dan Bisnis Sriwijaya Vol.12, no. No.1 (Maret 2014).

Ilham Bashirudin, Erlangga Fausa, dan Amarria Dila Sari. "IMPLEMENTASI ERP SAP DALAM PEMBUATAN REPORT DEMOGRAFI ORGANISASI (Studi Kasus PT. Krakatau Steel 
(Persero) Tbk.).” Jurnal Teknologi Informasi Vol.23, no. No.3 (September 2017).

Elisabet Yunaeti, dan Rita Irviani. Pengantar Sistem Informasi. Yogyakarta: ANDI, 2017.

Yusdiardi. "Rancang Bangun Sistem Informasi Penjualan (Studi Kasus : PT.I-Cube Creativindo)." Sains dan Teknologi, 2014.

Safitri, Pipit Kurnia, Wing Wahyu Winarno, dan Eko Pramono. "Optimasi Query untuk Sistem Informasi Penjadwalan Mata Pelajaran Sekolah Menggunakan View (Studi Kasus : SMK VIP Purworejo).” Jurnal Teknologi Informasi Vol.XIII, no. No.2 (Juli 2018).

Harizal Irawan. "Perancangan Sistem Informasi Administrasi Kesiswaan pada SMP Negeri 4 Muntok dengan Berorientasi Objek.” Jurnal Sifom, 2014.

Darman Umagapi, dan Arisandy Ambarita. "Sistem Informasi Geografis Wisata Bahari pad Dinas Pariwisata." ILKOMINFO, Juli 2018.

Titin Sri Handayani, dan Indah Uly Wardati. “Analisis dan Perancangan Sistem Informasi Pengolahan Data Persediaan Obat Pada Pos Kesehatan Desa Wonoanti." IJCSS, 2014.

Eka Iswandy. "Sistem Penunjang Keputusan untuk Menentukan Penerimaan Dana Satuan Sosial Anak Nagari dan Penyaluranya Bagi Mahasiswa dan Pelajar Kurang Mampu di Kenagarian Barung-Barung Balantai Timur." Jurnal TEKNOF Vol.3, no. No.2 (Oktober 2015): 73.

Nur Laila, dan Wahyuni. "Sistem Informasi Pengolahan Data Inventory pada Toko Buku (Studi Cv. Aneka Ilmu Semarang)." Jurnal Teknik Elektro Vol. 3, no. No.1 (2011).

Indra. Analisis dan Desain. Jakarta: PT Elex Media Kompotindo, 2010.

Adelia, dan Jimmy Setiawan. "Implementasi Customer Relationship Management (CRM) pada Sistem Reservasi Hotel berbasis Website dan Desktop." Jurnal Sistem Informasi Vo.6, no. No.2 (September 2011).

Sri Haryanti, dan Tri Irianto. "Rancang Bangun Sistem Informasi E-Commerce untuk Usaha Fashion Studi Kasus Omah Mode.” Jurnal Speed Vol.3, no. No.1 (2011).

Desi Vera Sundawa Putri, Asep Deddy, dan Bunyamin. "Perancangan Aplikasi Media
Pembelajaran Pendidikan Lingkungan Hidup untuk Siswa Kelas VI Sekolah Dasar Berbasis Android." Jurnal Algoritma Vol.11, no. No.1 (2014).

Ade hendini. "PEMODELAN UML SISTEM INFORMASI MONITORING PENJUALAN DAN STOK BARANG (STUDI KASUS: DISTRO ZHEZHA PONTIANAK)." JURNAL KHATULISTIWA INFORMATIKA Vol.4 (Desember 2016).

Soekarta, R. (2015). RANCANG BANGUN SISTEM AKADEMIK BERBASIS WEB (Studi Kasus Universitas Muhammadiyah Sorong).Insect (Informatics and Security) : Jurnal Teknik Informatika, 1)1), 1-8.

Stafeno. (2014). Cara Mudah Membangun Sistem Informasi Menggunakan VB.Net dan Komponen Dexperince. Yogyakarta: Andi.

Sudharyana, P., \& Dkk. (2012). Rancang Bangun Sistem Penilaian Indek Kepuasan Pegawai Terhadap Lingkungan Kerja Melalui Dasbhord Terintegrasi Dengan Menggunakan Metode Prototipe Studi Kasus PT. PLN (Persero) Area Bali Selatan. Teknik Pomits, 1(1), 1-6.

Sukamanto, R. A., \& Shalahudin, M. (2014). Rekayasa Perangkat Lunak Terstruktur Dan Berorientasi Objek. Bandung: Informatika Bandung.

Susanto, A. (2013). Sistem Informasi Akuntansi. Bandung: Lingga Jaya.

Sutabri, T. (2012). Analisis Sistem Informasi. Yogyakarta: Andi Offset.

Tantara, \& Rudi. (2012). Manajeman Proyek Sistem Informasi. Jakarta: Erlangga.

Taufiq, R. (2016). Fakta Menakjubkan Tentang Internet. www.liputan6.com.

Vickyantoro, H. (2014). Pembuatan Sistem Informasi Reservasi Kamar Menggunakan Visul Basic.NET Pada Hotel Omah'e Sun Condongcatur Yogyakarta. Yogyakarta: Sekolah Tinggi Manajemen Informatika Dan Komputer.

Wahono, R. (2007). Sistem Informasi Penginapan Wisma Assalam. Surakarta: Fakultas Matematika Dan Ilmu Pengetahuan Alam Universitas Sebelas Maret Surakarta.

Wibowo, B. (2014). Rancang Bangun Sistem Informasi Reservasi Reservasi Sewa Kamar Hotel Berbasis Web (Studi Kasus Hotel Gren Mandarin Pekalongan). Semarang: Fakultas Teknologi Informasi. 